\title{
Use of nanoencapsulated curcumin against vegetative cells and spores of Alicyclobacillus spp. in industrialized orange juice
}

\author{
Tatiane Viana Dutra ${ }^{a}$, Jéssica Lima de Menezes ${ }^{a}$, Amanda Gouveia Mizuta ${ }^{a}$, \\ Anielle de Oliveira ${ }^{a, b}$, Thaysa Fernandes Moya Moreira ${ }^{\mathrm{a}, \mathrm{b}}$, Lillian Barros ${ }^{\mathrm{c}}$, Filipa Mandim ${ }^{\mathrm{c}}$, \\ Carla Pereira ${ }^{c}$, Odinei Hess Gonçalves ${ }^{b, c}$, Fernanda Vitória Leimann ${ }^{\text {b,c }}$, \\ Jane Martha Graton Mikcha ${ }^{\mathrm{d}}$, Miguel Machinski Junior ${ }^{\mathrm{e}}$, Benício Alves de Abreu Filho ${ }^{\mathrm{a}, \mathrm{e}, *}$ \\ ${ }^{a}$ Graduate Program in Food Science (PPC), State University of Maringá (UEM), Av. Colombo, 5790, 87020-900 Maringá, Brazil \\ b Graduate Program in Food Technology (PPGTA), Federal Technological University of Paraná, Campus Campo Mourão (UTFPR-CM), Via Rosalina Maria dos Santos, \\ 1233, 87301-899, Campo Mourão, Brazil \\ ${ }^{\mathrm{c}}$ Centro de Investigação de Montanha (CIMO), Instituto Politécnico de Bragança, Campus de Santa Apolónia, 5300-253 Bragança, Portugal \\ d Department of Clinical Analysis and Biomedicine, State University of Maringá, Av. Colombo, 5790, Maringá, 87020-900, Paraná, Brazil

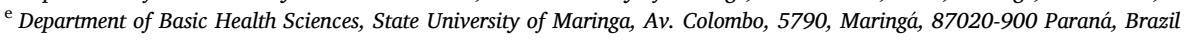

\section{A R T I C L E I N F O}

\section{Keywords:}

Spores

Curcumin-loaded nanoparticles

In natura curcumin

Orange juice

Antimicrobial activity

\begin{abstract}
A B S T R A C T
Pathogenic and deteriorating bacteria are a great concern to food safety. In this sense, the present study evaluated the fight against microbial contamination through the use of nanoparticles containing curcumin, in addition to analyzing the physical properties of these nanoparticles. Efficient curcumin encapsulation was determined by Fourier transform infrared spectra evaluation and differential scanning calorimetry. Transmission electron microscopy images showed irregular shaped nanoparticles with broad size distribution (20-250 nm). The antibacterial activity was considered satisfactory, since curcumin in the form of nanoparticles demonstrated antimicrobial and antibacterial activity superior to curcumin in its free form, against both pathogenic bacteria, such as Staphylococcus aureus (MIC $125 \mu \mathrm{g} / \mathrm{mL}$ ), and deteriorates, such as Alicyclobacillus acidoterrestris (MIC 62.5 $\mu \mathrm{g} / \mathrm{mL}$ ). Since curcumin nanoparticles may be consumed as a food additive, the bioactive properties of the nanoencapsulated curcumin were also evaluated in relation to antioxidant capacity (Thiobarbituric acid reactive substances (TBARS) and oxidative hemolysis inhibition assays) and cytotoxicity against four carcinoma cell lines, as well as two non-tumor cells. As a proof of concept, nanoparticles were incorporated in orange juice, with the juice maintaining satisfactory $\mathrm{pH},{ }^{\circ} \mathrm{Brix}$, and color stability, during three days of storage $\left(8{ }^{\circ} \mathrm{C}\right)$.
\end{abstract}

\section{Introduction}

The food production and consumption chains are increasingly concerned about the microbiological safety of food. There are several disinfection methods available and already implemented in the food industry; however, techniques that do not alter the organoleptic properties of foods are still lacking (Spricigo et al., 2013).

According to the World Health Organization, Salmonella spp. and Staphylococcus aureus are among the main bacteria that cause foodborne diseases (FBDs) (WHO, 2018). In addition to these, there are other significant microorganisms responsible for FBDs, such as species of Alicyclobacillus, which are Gram-positive and thermoacidophilic bacteria.
These bacteria are capable of multiplying in a wide range of $\mathrm{pH}$ (2.5-6.0) and temperature $\left(25-60^{\circ} \mathrm{C}\right)$, and some species can even form spores as a resistance mechanism. Alicyclobacillus spp. are associated with the deterioration of citrus juices, concentrates, teas, and tomato extracts due to inefficient pasteurization processes (Cai et al., 2019; Wang et al., 2018). Of the 22 species that comprise this genus, A. acidoterrestris is considered the most important deteriorate as it can produce by-products, such as guaiacol, which causes the astringent taste and odor in juices (Chang and Kang, 2004; Ciuffreda et al., 2015; Goto et al., 2002).

Due to the characteristics of sporulation and biofilm formation, the industry seeks alternatives for the control of Alicyclobacillus spp. in food

\footnotetext{
* Corresponding author at: Department of Health Sciences, State University of Maringá, Colombo Avenue 5790, University Campus, 87020-900, Block T20, $3^{\circ}$ Floor, Room 312, Maringá, Paraná, Brazil.

E-mail address: baafilho@uem.br (B.A. Abreu Filho).
} 
processing. The main objective, in addition to combating the microorganism, is to maintain the product's sensory characteristics. As the conventional pasteurization process is not able to eliminate Alicyclobacillus spp., alternatives have been investigated, including high hydrostatic pressure, ultraviolet radiation, natural antimicrobials, pulsed electric fields, ultrasound, pulsed light, or a combination of these processes with mild thermal treatments (Tremarin et al., 2019). Another promising approach that can be evaluated is the use of natural extracts with antimicrobial properties (Bevilacqua et al., 2008).

Some efforts have been made in the search for substances of natural origin with action against Alicyclobacillus spp., such as the use of papain and bromelain, which are proteolytic enzymes derived from papaya and pineapple, respectively (Anjos et al., 2016). Both enzymes were evaluated against strains of $A$. acidoterrestris, A. hesperidum, A. acidiphilus, A. cycloheptanicus, and $A$. acidocaldarius. The enzymes were reported to have effective inhibitory and bactericidal activity at low concentrations against all the strains except $A$. acidocaldarius. In another study, oregano (Origanum vulgare) essential oil was evaluated against the same strains, and was shown to efficiently control the growth of Alicyclobacillus spp. (Dutra et al., 2019). The authors highlighted the correlation between the good antioxidant activity of the compounds present in the essential oil, such as carvacrol acetate, and the antimicrobial activity of the natural product. Other natural extracts have also been studied against Alicyclobacillus spp., such as rosemary extract (Piskernik et al., 2016), green tea kombucha (Mizuta et al., 2020), Piper peltatum and Piper marginatum extracts (Pascoli et al., 2018), and thymol (Cai et al., 2019).

A largely studied natural antimicrobial compound is curcumin (diferuoyl methane), which is the major component within the phenolic compounds of Curcuma longa L. Curcumin has received considerable attention for its therapeutic properties, such as anti-inflammatory, anticancer, and antioxidant, as well as its antibacterial capacity (Gonçalves et al., 2020). Curcumin is already used in the food industry as a stabilizing agent or natural colorant (Mangolim et al., 2014; Mahmood et al., 2015), however its applicability is limited due to its poor water solubility. The encapsulation of poorly water-soluble compounds is a viable solution to overcome this problem. Generally Recognized as Safe (GRAS) materials can be used as encapsulating agents, thus increasing the range of foodstuff to which curcumin could be applied.

In view of the therapeutic potential of curcumin, Shah et al. (2018) evaluated the effects of nanoconjugates of curcumin and Ag (C-AgNPs) against skin cancer in patients. The authors reported better anti-cancer activity for the C-AgNPs conjugate $\left(\mathrm{AgNO}_{3}, 10-3 \mathrm{M}\right.$, mixed with $10-5$ $\mathrm{M}$ curcumin solution) than for the curcumin alone, suggesting its use as a chemotherapeutic agent for the treatment of cancer.

Solid dispersion is one of the encapsulation strategies that can be applied to obtain a water-soluble product from a hydrophobic compound, such as curcumin. Solid dispersions can be achieved by spray drying, melt extrusion, wet milling, and dissolution techniques. In the dissolution approach, a solvent that is able to solubilize both, the compound of interest and the encapsulating agent (polymer), is used (mainly ethanol), together with a surfactant. This mixture is submitted to a shearing process (ultrasound, rotor-stator systems, etc.) that increases the interaction between the encapsulating agent (carrier) and the encapsulated compound by means of hydrogen bonding (Karavas et al., 2006; Phunpee et al., 2018). The mixture may then be dried, forming a homogeneous amorphous solid solution, where the encapsulated compound and carrier are totally miscible and soluble. This approach is considered easier to apply and less expensive than other encapsulation procedures(Leimann et al., 2019).

The encapsulation of curcumin using the dissolution approach of solid dispersion was applied by H. H. S. Almeida et al., 2018; M. Almeida et al., 2018. The encapsulating material used by the authors was polyvinylpyrrolidone (PVP), while Tween 80 was used as a surfactant and sonication as means of promoting the interaction of the compounds. The antimicrobial action of the nanoparticles was investigated against Pseudomonas aeruginosa, Morganella morganii, Klebsiella pneumoniae
ESBL (spectrum extended producer), Klebsiella pneumoniae, Escherichia coli, Escherichia coli ESBL, Listeria monocytogenes, Enterococcus faecalis, methicillin-resistant Staphylococcus aureus, and methicillin-sensitive Staphylococcus aureus. Results showed minimal inhibition concentration (MIC) values between 0.5 and $1 \mathrm{mg} / \mathrm{mL}$.

With the aim of producing a safe antimicrobial agent to be applied in the food industry, and that does not alter the organoleptic and sensory properties of the product, curcumin nanoencapsulated in PVP was evaluated. Fig. 1 shows a schematic illustration of the steps evaluated. Here, the effect of curcumin was tested against Alicyclobacillus spp., important bacteria, being some highly food potentially spoilage species, as until now, there is no literature regarding in natura (unencapsulated) or nanoencapsulated curcumin against species of this genus. Furthermore, as a proof of concept, the incorporation of the nanoparticles in orange juice was evaluated in terms of the color, $\mathrm{pH}$, and ${ }^{\circ} \mathrm{Brix}$ of the product.

\section{Material and methods}

\subsection{Bacterial strains and reagents}

The bacterial strains used were: Alicyclobacillus acidoterrestris DSMZ $3922^{\mathrm{T}}$ (CBMAI 0244 $^{\mathrm{T}}$ ), A. herbarius DSMZ $13609^{\mathrm{T}}$ (CBMAI 0246 $^{\mathrm{T}}$ ),

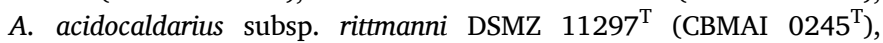
A. sendaiensis KCTC 3843, A. hesperidum DSMZ $12489^{\mathrm{T}}\left(\right.$ CBMAI $0298^{\mathrm{T}}$ ), and $A$. acidocaldarius DSMZ $446^{\mathrm{T}}$ (CBMAI $0299^{\mathrm{T}}$ ). These strains were obtained from the German Collection of Microorganisms and Cell Culture (DSZM - Deutsche Sammlung Von Mikroorganismen und Zellkulturen). Furthermore, Salmonella enterica serotype Enteritidis ATCC 13076 and Staphylococcus aureus ATCC 25923 strains were evaluated.

Curcumin (from Curcuma longa (Turmeric), $\geq 65 \%$; Sigma-Aldrich), polyvinylpyrrolidone (PVP, average mol wt 40,000; Sigma-Aldrich), Tween 80 (Dinâmica), and absolute ethanol (P.A.; Dinâmica) were used to obtain the curcumin nanoparticles by solid dispersion. Methanol, dimethyl sulfoxide (DMSO), petroleum ether, and absolute ethanol (P.A.; Dinâmica), potassium bromide (spectroscopy grade; SigmaAldrich) were used in the nanoparticle analysis. Concentrated pasteurized orange juice was obtained from the company Louis Dreyfus (LDC, Paranavaí-PR, Brazil).

\subsection{Preparation of bacterial suspensions}

\subsubsection{Bacterial suspension}

The suspensions of the microorganisms, A. acidoterrestris, A. herbarius, $A$. acidocaldarius, $A$. sendaiensis, $A$. hesperidum and $A$. acidocaldarius subsp. rittmanni, were prepared by inoculating bacterial colonies from a culture plate onto BAT (Bacillus acidoterrestris) medium (Deinhard et al., 1987), in BAT broth and stored in an oven at $45^{\circ} \mathrm{C}$ for $24 \mathrm{~h}$. After the suspensions were diluted in BAT broth according to the McFarland 0.5 scale, to obtain a concentration of $1.0 \times 10^{4} \mu \mathrm{g} / \mathrm{mL}$, and from the suspensions, serial dilution in 96-well plates for analysis of minimum inhibition and bactericidal concentration (MIC and MBC) was performed.

The same procedure was followed for the preparation of bacterial inoculum from Salmonella Enteritidis and Staphylococcus aureus, only replacing the agar and BAT broth with Mueller Hinton (MH) agar and broth, and stored in an oven at $35^{\circ} \mathrm{C}$ for $24 \mathrm{~h}$.

\subsubsection{A. acidoterrestris spores}

Standard spore suspensions were prepared from five colonies grown on BAT medium agar (Bacillus acidoterrestris medium) (Deinhard et al., 1987); that were collected with a cell culture sowing loop and transferred to tubes containing $3 \mathrm{~mL}$ of the same medium. The suspension was incubated at $45{ }^{\circ} \mathrm{C}$ for $24 \mathrm{~h}$, then $0.3 \mathrm{~mL}$ was subsequently resuspended in $10 \mathrm{~mL}$ of BAT broth and again incubated at $45^{\circ} \mathrm{C}$ for $72 \mathrm{~h}$. The culture was transferred to a cryotube, centrifuged for $1 \mathrm{~min}$ at $10,000 \mathrm{rpm}$, followed by three washes with sterile distilled water, then stored under 


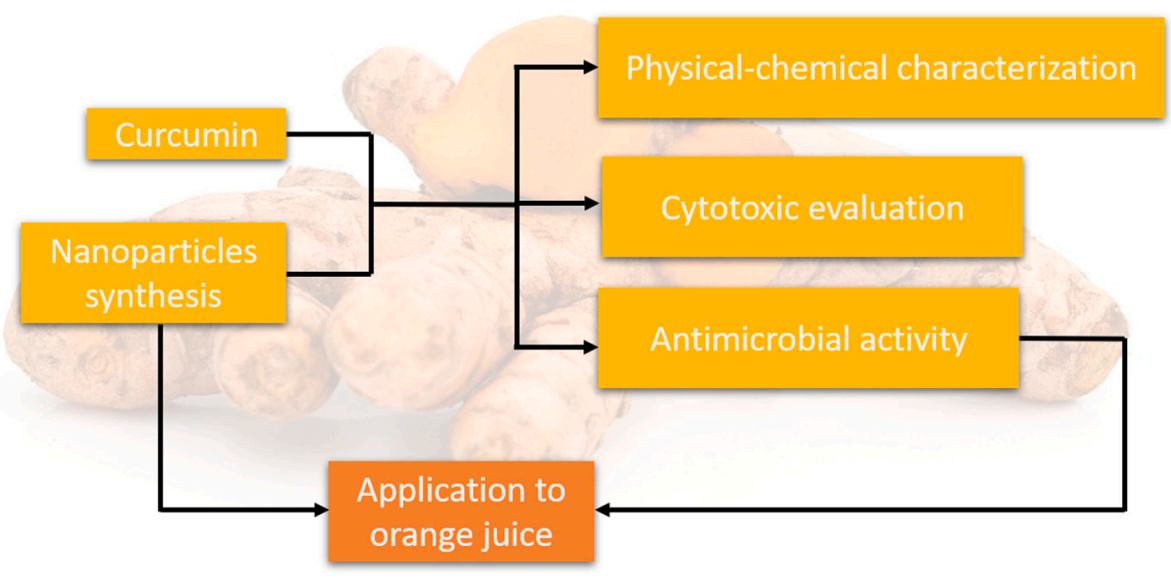

Fig. 1. Schematic illustration of curcumin nanoparticles evaluation.

refrigeration at $5{ }^{\circ} \mathrm{C}$ until use.

\subsection{Curcumin nanoparticles obtained by solid dispersion}

Curcumin nanoparticles were obtained by the dissolution approach of solid dispersion, according to Karavas et al. (2006) and Miranda et al. (2016) with minor modifications. PVP (100 mg) was dissolved in ethanol $(27.5 \mathrm{~mL})$ under gentle stirring, after which curcumin $(10 \mathrm{mg})$ and tween $80(10 \mathrm{mg})$ were added and stirring was maintained for 5 min. The mixture was then submitted to sonication ( $120 \mathrm{~W}$ and $1 / 8^{\prime}$ tip; Fisher Scientific) for 5 min under a pulse condition of 30s on and 10 s off. Temperature was controlled with an ice bath. Finally, the solid dispersion was dried in a forced air oven at $40^{\circ} \mathrm{C}$ for $4 \mathrm{~h}$.

\subsection{Nanoparticle characterization}

\subsubsection{Fourier Transform Infrared Spectroscopy (FTIR)}

Fourier transform infrared (FTIR) spectra were acquired using a Shimadzu IRAffinity-1. Samples (PVP, in natura curcumin, curcumin nanoparticles, and a physical mixture of curcumin and PVP prepared in a mortar in the same proportions as used for the nanoparticles) were pelletized with potassium bromide, and spectra were collected with a resolution of $4 \mathrm{~cm}^{-1}$, by combining 32 scans in the spectral range of 4000 to $400 \mathrm{~cm}^{-1}$.

\subsubsection{Morphological characterization}

Morphological characterization of the nanoparticles was performed using transmission electron microscopy (TEM; JEOL model JEM 2100, $200 \mathrm{kV}$ ). The nanoparticle solid dispersion was diluted in distilled water $(0.1 \% \mathrm{w} / \mathrm{v})$ and dripped onto 400 mesh formvar/carbon covered copper grids. Before the analysis, grids were kept at room temperature in a desiccator with silica.

\subsubsection{Thermal characterization}

Thermal properties of the nanoparticles were investigated by differential scanning calorimetry (DSC; Perkin Elmer 4000). Samples (PVP, in natura curcumin, curcumin nanoparticles, and a physical mixture of curcumin and PVP in the same proportion as the nanoparticles) were inserted in sealed aluminum pans and analyzed under nitrogen flow (50 $\mathrm{mL} / \mathrm{min}$ ) and heated from 20 to $300{ }^{\circ} \mathrm{C}$ at $20^{\circ} \mathrm{C} / \mathrm{min}$.

\subsection{Antibacterial and bactericidal activity}

Minimum inhibitory (MIC) and bactericidal (MBC) concentrations were determined using the 96-well microplate microdilution technique according to CLSI (2012) methodology, M7-A9. For the inoculum activation, discontinuous streaks were performed on Petri dishes containing specific growth agar, BAT agar for Alicyclobacillus spp. incubated at $45{ }^{\circ} \mathrm{C}$ for $24 \mathrm{~h}$, and Mueller Hinton (MH) agar for Salmonella Enteritidis and Staphylococcus aureus, incubated at $35{ }^{\circ} \mathrm{C}$ for $24 \mathrm{~h}$. Colonies were then isolated and cultures were pre-activated for $24 \mathrm{~h}$ before test by seeding in the specific media and growing at the respective temperatures for each microorganism. In natura curcumin was dissolved in DMSO and BAT medium, the nanoparticles were dissolved in BAT or MH medium, according to the bacteria to be tested in the assay, and these were added to the first wells of a 96-well plate at an initial concentration of $2000 \mu \mathrm{g} /$ $\mathrm{mL}$ and then serially diluted. The bacterial inoculum was diluted according to the McFarland 0.5 scale $\left(10^{8} \mathrm{CFU}\right)$, and then $5 \mu \mathrm{L}$ of the bacterial suspension was added to each well of the 96-well plate and the plate was incubated at $45^{\circ} \mathrm{C}$ for $24 \mathrm{~h}$. The MIC was determined by visual analysis of turbidity. For the MBC, $10 \mu \mathrm{L}$ of each well was plated on BAT and $\mathrm{MH}$ agar plates in triplicate, followed by incubation at $45^{\circ} \mathrm{C}$ for 24 $\mathrm{h}$, to see whether there was any subsequent growth. The same test was applied to the spores of $A$. acidoterrestris.

\subsection{Cytotoxic evaluation}

The cell lines of human tumors used in the cytotoxicity analysis were obtained from the Leibniz DSMZ Institute - German Collection of Microorganisms and Cell Cultures.

The evaluation of cytotoxicity was performed for the curcumin nanoparticles, as well as the PVP and curcumin alone, using the following cell lines of human tumors: gastric adenocarcinoma (AGS), breast adenocarcinoma (MCF-7), non-small cell lung carcinoma (NCI60 ), and colorectal adenocarcinoma (Caco-2). Non-tumor liver primary culture (PLP2), established by our lab, and non-tumor culture from African green monkey (Vero) obtained from the ECCAC, were also evaluated. The cell lines were incubated in RPMI-1640 containing heatinactivated fetal bovine serum (FBS; 10\%), glutamine ( $2 \mathrm{mM}$ ), penicillin $(100 \mathrm{U} / \mathrm{mL})$, and streptomycin $(100 \mu \mathrm{g} / \mathrm{mL})$, and incubated at $37{ }^{\circ} \mathrm{C}$ with humidified air and $5 \% \mathrm{CO}_{2}$.

Each cell line was prepared at $1.0 \times 10^{4}$ cells/well in 96-well microplates and incubated for $24 \mathrm{~h}$ to allow cell attachment. The compounds were added at specific concentrations $(0,5 \mu \mathrm{g} / \mathrm{mL}$ of the concentration of $1.0 \times 10^{4}$ cells/well) and incubated for a further $48 \mathrm{~h}$. Thereafter, cold trichloroacetic acid $(10 \%, 100 \mu \mathrm{L})$ was added to fix the cells, and allowed to stand for $1 \mathrm{~h}$ at $4{ }^{\circ} \mathrm{C}$. The plates were then washed 3 times with deionized water and air-dried. SRB solution $(0.1 \%$ sulforhodamine B in $1 \%$ acetic acid, $100 \mu \mathrm{L}$ ) was added and the plate was incubated at room temperature for $30 \mathrm{~min}$. The plates were then washed with acetic acid (1\%) to remove excess SRB and allowed to air dry. Finally, adhered SRB was solubilized by the addition of Tris-HCl (10 $\mathrm{mM}, 200 \mu \mathrm{L}$ ) and the plate was read at $540 \mathrm{~nm}$ in a microplate reader (BioTek ELx800). For each cell line tested, the $\mathrm{GI}_{50}$ values, 
corresponding to the concentration of extract that inhibited $50 \%$ of cell growth, was calculated. Two independent experiments were performed, each one carried out in duplicate and the results are expressed as mean values and standard deviation (SD). Ellipticine was used as a positive control (Abreu et al., 2011).

\subsection{Antioxidant capacity}

\subsubsection{Antihemolytic activity}

The antihemolytic activity of the nanoparticles, PVP, and curcumin was evaluated by the oxidative hemolysis inhibition assay (OxHLIA) described previously by Takebayashi et al. (2012) with some modifications. Sheep blood samples were collected from healthy animals and centrifuged for $5 \mathrm{~min}$ at $1000 \mathrm{~g}$ and $10{ }^{\circ} \mathrm{C}$. Plasma and buffy coats were discarded and erythrocytes were first washed once with $\mathrm{NaCl}(150 \mathrm{mM})$ followed by three washes with phosphate-buffered saline (PBS; pH 7.4) (Evans et al., 2013). The erythrocyte pellet was then resuspended in PBS at $2.8 \%(\mathrm{v} / \mathrm{v})$. Using a flat bottom 48 -well microplate, $200 \mu \mathrm{L}$ of erythrocyte solution was mixed with $400 \mu \mathrm{L}$ of either PBS solution (control), sample dissolved in PBS, or water (for complete hemolysis). Trolox was used as positive control. After pre-incubation at $37^{\circ} \mathrm{C}$ for $10 \mathrm{~min}$ with shaking, 2,2'-azobis(2-methylpropionamidine) dihydrochloride (AAPH; $160 \mathrm{mM}$ in PBS, $200 \mu \mathrm{L}$ ) was added and the optical density was measured at $690 \mathrm{~nm}$ (BioTek ELx800). After that, the plate was incubated under the same conditions and the optical density was measured every $10 \mathrm{~min}$ at the same wavelength for approximately $400 \mathrm{~min}$ (Takebayashi et al., 2012). The percentage of the erythrocyte population that remained intact $(\mathrm{P})$ was calculated according to Eq. (1).

$P(\%)=\left(\frac{S_{t}-C_{0}}{S_{0}-\mathrm{CH}_{0}}\right) \times 100$

where $S_{t}$ and $S_{0}$ correspond to the optical density of the sample at $t$ and 0 min, respectively, and $\mathrm{CH}_{0}$ is the optical density of the complete hemolysis at $0 \mathrm{~min}$. The results were expressed as delayed time of hemolysis $(\Delta t)$, which was calculated according to Eq. (2).

$\Delta \mathrm{t}(\min )=\mathrm{H}_{\mathrm{t} 50 \text { Sample }}-\mathrm{H}_{\mathrm{t} 50 \text { Control }}$

where $\mathrm{H}_{\mathrm{t} 50}$ is the $50 \%$ hemolytic time (min) obtained from the hemolysis curve of each antioxidant sample/control concentration. The $\Delta t$ values were then correlated to the antioxidant sample concentrations (Takebayashi et al., 2012) and, from the correlation obtained, the sample concentration able to promote a $\Delta \mathrm{t}$ hemolysis delay was calculated. The results were given as $\mathrm{IC}_{50}$ values $(\mu \mathrm{g} / \mathrm{mL}$ ) at $\Delta \mathrm{t} 60$, (i.e., sample concentration required to keep $50 \%$ of the erythrocyte population intact for $60 \mathrm{~min})$.

\subsubsection{Thiobarbituric Acid Reactive Substances (TBARS) assay}

For the TBARS assay, pig (Susscrofa) brain tissues were dissected and homogenized with Tris- $\mathrm{HCl}$ buffer $(20 \mathrm{mM}, \mathrm{pH} 7.4)$ to obtain a homogenate $(1: 2 \mathrm{w} / \mathrm{v})$. The brain tissue homogenate was then centrifuged at $3000 \mathrm{~g}$ for $10 \mathrm{~min}$ and the supernatant was collected. Nanoparticles, PVP, and curcumin samples $(0.2 \mathrm{~mL}$ at different concentrations dissolved in ethanol), together with $\mathrm{FeSO}_{4}(10 \mu \mathrm{M} ; 0.1 \mathrm{~mL})$ and ascorbic acid $(0.1 \mathrm{mM} ; 0.1 \mathrm{~mL})$, were incubated with the brain supernatant $(1: 2$ $\mathrm{w} / \mathrm{v} ; 0.1 \mathrm{~mL})$ at $37^{\circ} \mathrm{C}$ for $1 \mathrm{~h}$. Then, tri-chloroacetic $(28 \% \mathrm{w} / \mathrm{v} ; 0.5 \mathrm{~mL})$ and thiobarbituric (TBA; $2 \% \mathrm{w} / \mathrm{v} ; 0.38 \mathrm{~mL}$ ) acids were added and the mixture was heated at $80^{\circ} \mathrm{C}$ for $20 \mathrm{~min}$ and centrifuged $3000 \mathrm{~g}$ for $5 \mathrm{~min}$. The evaluation of the lipid peroxidation inhibition in porcine brain homogenates results from the reduction of TBARS by the formation of the malondialdehyde-thiobarbituric acid complex (MDA-TBA). The color intensity displayed by this complex was measured by absorbance at $532 \mathrm{~nm}$ (UV-Vis Specord 200 spectrophotometer, Analytik Jena, Jena, Germany). The results were expressed in values of $\mathrm{IC}_{50}$, the concentration of sample necessary to obtain $50 \%$ of antioxidant activity (Santos et al., 2019).

\subsection{Incorporation of nanoencapsulated curcumin in orange juice}

The nanoencapsulated curcumin was incorporated in the orange juice in two concentrations, based on the MIC results for the most resistant microorganism among the Alicyclobacillus spp. evaluated (A. herbarius $0246^{\mathrm{T}}$ with an MIC of $125 \mu \mathrm{g} / \mathrm{mL}$ ). First, concentrated and frozen orange juice $\left(61.5^{\circ} \mathrm{Brix}\right)$ was reconstituted with water $\left(11.1^{\circ} \mathrm{Brix}\right)$. After that, $50 \mathrm{~mL}$ samples were separated into four groups in triplicate: 1) control group (reconstituted juice), 2) $1 \times$ MIC (with nanoencapsulated curcumin added at a concentration equivalent to the MIC, which was $125 \mu \mathrm{g} / \mathrm{mL}$ ), 3) $5 \times$ MIC (with nanoencapsulated curcumin added at a concentration equivalent to 5-fold MIC, which was $125 \times 5=525 \mu \mathrm{g} / \mathrm{mL}$ ), and 4) $10 \times$ MIC (with nanoencapsulated curcumin added at a concentration equivalent to 10 -fold MIC, which was $125 \times 10=1250 \mu \mathrm{g} / \mathrm{mL}$ ). The samples were homogenized with a magnetic stirrer. The technological properties of color, $\mathrm{pH}$, and ${ }^{\circ} \mathrm{Brix}$ were evaluated just after sample preparation and after 3 days of storage (common shelf life of a juice prepared at home by the reconstitution of a commercial concentrated orange juice) in the fridge $\left(8 \pm 2{ }^{\circ} \mathrm{C}\right)$.

For the color parameter determination, a Delta Vista 450G (Delta Color) colorimeter coupled with a liquid measurement accessory was used. A $4 \mathrm{~mm}$ measuring aperture was applied for the measurements of the CIELAB system parameters: $\mathrm{L}^{*}$ (lightness), $\mathrm{a}^{*}$ (from green $(-)$ to red $(+)$ ), and $b^{*}$ (from blue $(-)$ to yellow $(+)$ ). Also, chroma $\left(C^{*}\right)$ and hue angle $\left(\mathrm{h}^{\circ}\right)$ were determined. The $\mathrm{pH}$ was determined with a Gehaka (PG 2000) $\mathrm{pH}$ meter, and the ${ }^{\circ}$ Brix with a bench refractometer (RMT, BEL Engineering). All readings of each sample were performed in triplicate.

To evaluate the antimicrobial effect of the nanoparticle in the food matrix, A. acidoterrestris $0244^{\mathrm{T}}$ was used for the subsequent assays, as it is the main spoiler of orange juice, and the best result for the in vitro antimicrobial activity was obtained for this strain. Using nanoparticle concentrations equivalent to the MIC for this strain, $1 \times$ MIC $(62.5 \mu \mathrm{g} /$ $\mathrm{mL}), 4 \times \mathrm{MIC}(250 \mu \mathrm{g} / \mathrm{mL})$, and $8 \times \mathrm{MIC}(500 \mu \mathrm{g} / \mathrm{mL})$ were tested for their antimicrobial potential in the orange juice.

The concentrated orange juice was reconstituted with sterile water to a concentration of $11^{\circ}$ Brix. In 24-well plates, negative control wells received only the reconstituted juice, and positive control wells received the juice and inoculum of $A$. acidoterrestris $0244^{\mathrm{T}}$ at $5 \mu \mathrm{L} / \mathrm{mL}$, as described in Section 2.5. In the other wells, different concentrations of the nanoparticles were added to the orange juice and bacteria suspension. The plate was incubated at $45{ }^{\circ} \mathrm{C}$ for $24 \mathrm{~h}$. After this, $10 \mu \mathrm{L}$ of each well was plated on BAT agar plates followed by further incubation at $45{ }^{\circ} \mathrm{C}$ for $24 \mathrm{~h}$, and then counting to determine the reduction rate obtained by the use of nanoparticles.

\subsection{Statistical analysis}

The Student's $t$-test, analysis of variance (ANOVA), and the Tukey test at a significance level of $5 \%(P<0.05)$ were used to evaluate the antioxidant capacity data in the Statistica 7.0 software (Statsoft Inc., Tulsa, OK, USA, 2004). Factorial ANOVA and Tukey's test $(P<0.05)$ were applied to color, $\mathrm{pH}$, and ${ }^{\circ}$ Brix data in Statistica 7.0 (Statsoft, USA). Statistical analysis was performed using one-way analysis of variance (ANOVA) and Tukey's multiple-comparison posttest. Differences between groups were considered to be significant at a $P$ value of $<0.05$. Statistical analyses were performed with GraphPad Prism 9.0 (GraphPad Software, Inc., San Diego, CA).

\section{Results and discussion}

\subsection{Nanoparticle characterization}

Fig. 2 shows the FTIR spectra of curcumin-loaded nanoparticles, a physical mixture of PVP and curcumin, and curcumin and PVP alone.

It was possible to observe the characteristic bands of the curcumin aromatic ring at $1605 \mathrm{~cm}^{-1}(\mathrm{C}-\mathrm{C})$ and $1508 \mathrm{~cm}^{-1}(\mathrm{C}=\mathrm{C})$ (Lemes et al., 


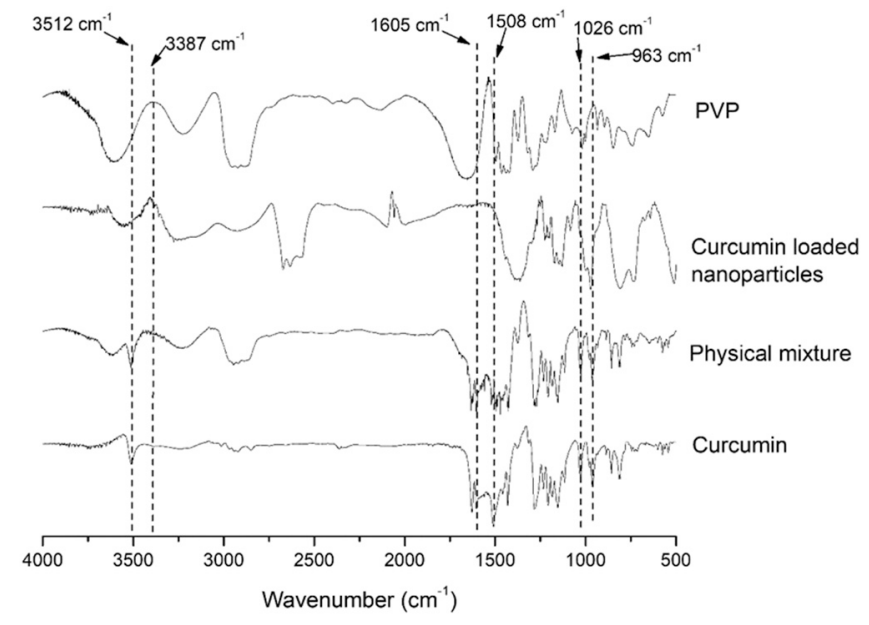

Fig. 2. FTIR spectra: PVP; to curcumin, PVP and curcumin physical mixture; curcumin loaded nanoparticles.

2017) in the free-form curcumin and the physical mixture of the compounds (curcumin and PVP), while these bands were attenuated in the nanoparticle spectra. This behavior suggests that some degree of interaction between curcumin and PVP took place in the nanoparticles, in addition to the curcumin entrapment. Furthermore, the stretching vibration of curcumin -OH can be observed at 3512 and $3387 \mathrm{~cm}^{-1}$ in the curcumin and physical mixture spectra; however, in the spectra of the curcumin nanoparticles spectra, these bands cannot be visualized due the presence of a bandwidth relative to adsorbed water near $3550 \mathrm{~cm}^{-1}$. Also, other curcumin characteristic absorption bands can be observed at $1026 \mathrm{~cm}^{-1}$ (C-O groups) and $963 \mathrm{~cm}^{-1}$ (aromatic $\mathrm{C}-\mathrm{H}$ ) for the curcumin alone and the physical mixture, but these are greatly attenuated in the nanoparticle spectra, another indication of efficient encapsulation (Almeida et al., 2018a, 2018b; Silva de Sá et al., 2019).

Characterization analyses demonstrated that nanoparticles were formed (TEM images), curcumin was encapsulated properly, and the nanoparticles were stable (FTIR and DSC). In the chemical characterization analysis by FTIR, the interaction between the encapsulant bands of PVP and curcumin can be verified, as indicated by the decrease in spectrum intensity. This suggests that curcumin has been trapped efficiently, which makes the particle more soluble (Almeida et al., 2018a, 2018b). The absence of the curcumin melting temperature (Tm) for the nanoparticle samples, as determined by DSC, demonstrated that the curcumin is interacting with PVP in its amorphous form (Almeida et al., 2018a, 2018b).

The morphology of the nanoparticles can be observed in Fig. 3. Nanoparticles presented irregular shape, similar to that reported by Dong et al. (2018) who produced a solid dispersion of atorvastatin calcium with Pluronic 188, and by Almeida et al. (2018a, 2018b) who produced solid dispersions of curcumin in PVP. The size of the curcuminloaded nanoparticles identified in the TEM images varied between 20 and $250 \mathrm{~nm}$, which is in accordance with the results obtained by Almeida et al. (2018a, 2018b).

The thermal characterization of the curcumin-loaded nanoparticles is presented in Fig. 4. The melting temperature (Tm) of crystalline curcumin is clearly located at $175{ }^{\circ} \mathrm{C}$, as observed by other authors (Lemes et al., 2017). In relation to the PVP thermogram, an endothermic peak can be seen with maximum temperature of $70^{\circ} \mathrm{C}$, which is related to the evaporation of adsorbed water, since PVP is a highly hydrophilic polymer (Almeida et al., 2018a, 2018b). In the thermogram of the physical mixture, the curcumin Tm was detected with lower intensity

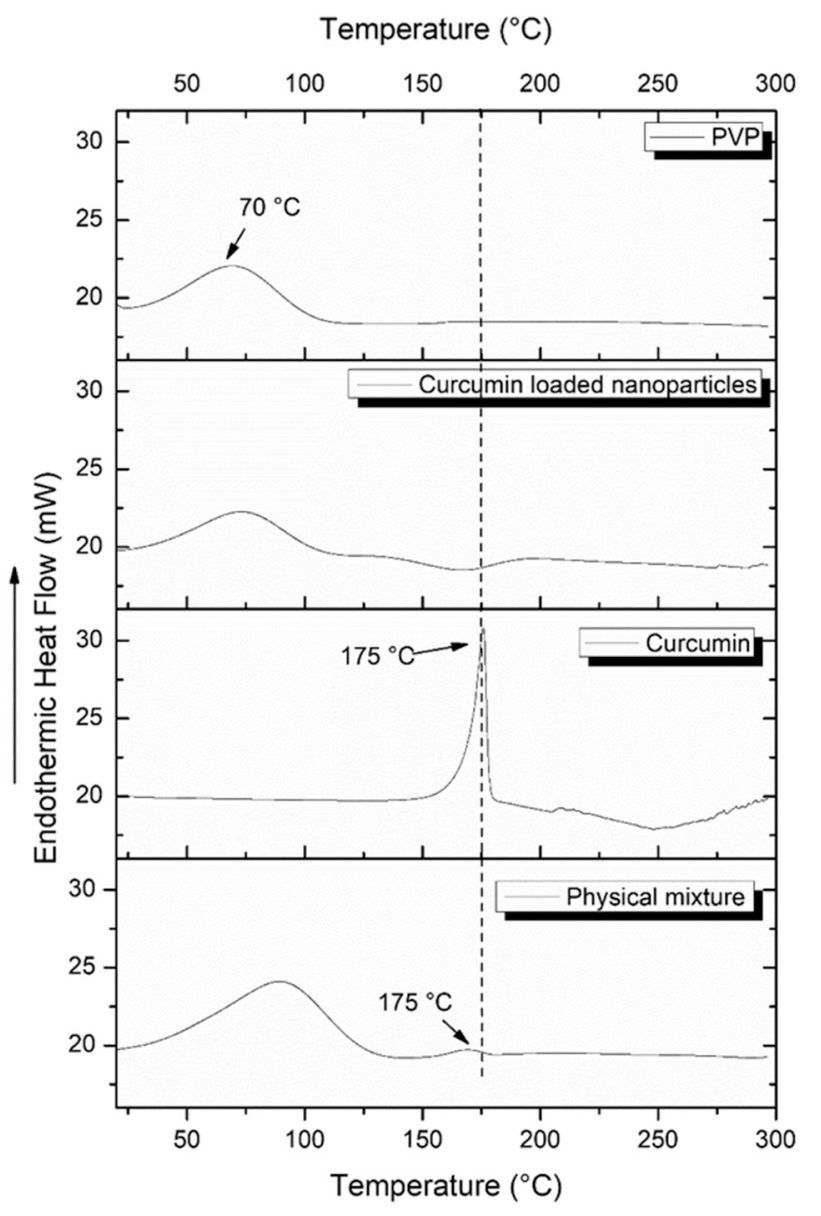

Fig. 4. DSC thermograms: PVP; to curcumin, PVP and curcumin physical mixture; curcumin loaded nanoparticles.

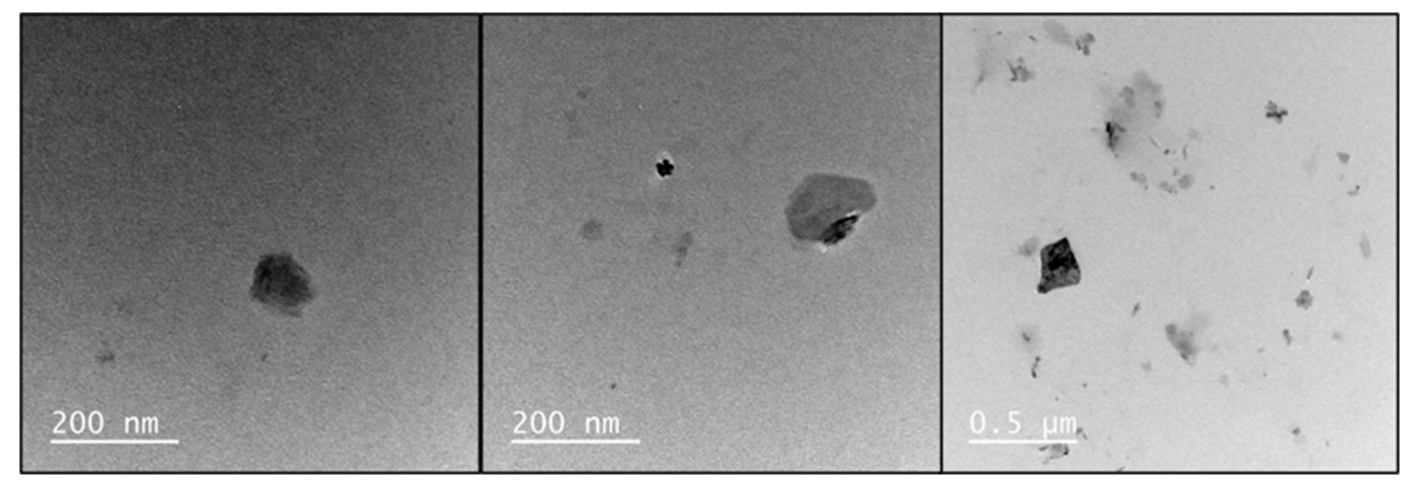

Fig. 3. Transmission electron microscopy of curcumin loaded nanoparticles. 
than observed for the curcumin alone due to its proportion in relation to PVP $(10 \% \mathrm{w} / \mathrm{w})$ in the mixture. In the curcumin-loaded nanoparticle thermogram, the curcumin $\mathrm{Tm}$ was not detected, which may be considered an indication that curcumin is in its amorphous form interacting with PVP (Silva de Sá et al., 2019).

\subsection{Antimicrobial activity}

The MIC and MBC results for encapsulated curcumin and in natura curcumin against the tested microorganisms are given in Table 1 . Results indicated that the in natura curcumin had poor activity against the microorganisms when compared to the nanoencapsulated curcumin. Typically, encapsulated curcumin presents advantages over its free form (non-encapsulated, or in natura), particularly regarding water solubility and bioavailability (Silva et al., 2018). Also, these nanoparticles are readily dispersible in water which favors the activity of the encapsulated compound (Almeida et al., 2018a, 2018b). Since in natura curcumin has low solubility in water, the compounds responsible for its antimicrobial activity are not freely available when in contact with the contaminated environment. However, in its nanoencapsulated form, with increased solubility, the compounds are released and ready to combat the microorganisms present, as observed in this study with greater antimicrobial activity observed for the curcumin in its nanoparticle form. The use of the nanoparticle technique, as demonstrated in our studies, can enhance the activity of novel antibacterial compounds with low solubility.

The sporicidal activity of curcumin nanoparticles against the spores of $A$. acidoterrestris was also evaluated. The encapsulated curcumin also presented superior action $(62.5 \mu \mathrm{g} / \mathrm{mL})$ against the spores than the in natura curcumin $(1000 \mu \mathrm{g} / \mathrm{mL})$, further proving the encapsulation efficiency of curcumin by the solid dispersion.

Lyu et al. (2020) evaluated the antimicrobial efficiency of silver nanoparticles $(\mathrm{Ag}$ ) combined with curcumin (C) in a complex with oxidized amylose (AO), using $S$. aureus as an example of a Gram-positive bacteria. The authors obtained similar results to the present work, where the AO-Ag-C together showed greater antimicrobial capacity when compared to the oxidized amylose with silver alone (AO-Ag) or with curcumin alone (AO-C). The concentration determined by the researchers was equal to $2.5 \mathrm{mg} / \mathrm{mL}$ of the $\mathrm{AO}-\mathrm{Ag}-\mathrm{C}$ solution, higher than the result found in this work (Table 1 ).

Mirzahosseinipour et al. (2020) evaluated, through antimicrobial photodynamic therapy, the action of nanoparticles of curcumin and silica delivered to planktonic cells of the Gram-positive $S$. aureus and the

Table 1

Minimum inhibitory concentration (MIC) and minimum bactericidal concentration (MBC) determined for curcumin-loaded nanoparticles and in natura curcumin.

\begin{tabular}{|c|c|c|c|c|}
\hline & \multicolumn{2}{|c|}{$\begin{array}{l}\text { Curcumin-loaded } \\
\text { nanoparticles }\end{array}$} & \multicolumn{2}{|c|}{ In natura curcumin } \\
\hline & $\begin{array}{l}\mathrm{MIC}(\mu \mathrm{g} / \\
\mathrm{mL})\end{array}$ & $\begin{array}{l}\mathrm{MBC}(\mu \mathrm{g} / \\
\mathrm{mL})\end{array}$ & $\begin{array}{l}\mathrm{MIC}(\mu \mathrm{g} / \\
\mathrm{mL})\end{array}$ & $\begin{array}{l}\mathrm{MBC}(\mu \mathrm{g} / \\
\mathrm{mL})\end{array}$ \\
\hline A. acdioterrestris $0244^{\mathrm{T}}$ & $\begin{array}{l}62.5 \pm \\
0.00\end{array}$ & $\begin{array}{l}500 \pm \\
0.00\end{array}$ & $\begin{array}{l}1000 \pm \\
0.00\end{array}$ & $\begin{array}{l}>1000 \pm \\
0.00\end{array}$ \\
\hline A. herbarius $0246^{\mathrm{T}}$ & $\begin{array}{l}125 \pm \\
0.00\end{array}$ & $\begin{array}{l}250 \pm \\
0.00\end{array}$ & $\begin{array}{l}>1000 \pm \\
0.00\end{array}$ & $\begin{array}{l}>1000 \pm \\
0.00\end{array}$ \\
\hline $\begin{array}{l}\text { A. acidocaldarius subsp. } \\
\text { rittmanni } 0245^{\mathrm{T}}\end{array}$ & $\begin{array}{l}62.5 \pm \\
0.00\end{array}$ & $\begin{array}{l}125 \pm \\
0.00\end{array}$ & $\begin{array}{l}>1000 \pm \\
0.00\end{array}$ & $\begin{array}{l}>1000 \pm \\
0.00\end{array}$ \\
\hline A. sendaiensis КСТС 3843 & $\begin{array}{l}125 \pm \\
0.00\end{array}$ & $\begin{array}{l}250 \pm \\
0.00\end{array}$ & $\begin{array}{l}>1000 \pm \\
0.00\end{array}$ & $\begin{array}{l}>1000 \pm \\
0.00\end{array}$ \\
\hline A. hesperidum $0298^{\mathrm{T}}$ & $\begin{array}{l}62.5 \pm \\
0.00\end{array}$ & $\begin{array}{l}125 \pm \\
0.00\end{array}$ & $\begin{array}{l}>1000 \pm \\
0.00\end{array}$ & $\begin{array}{l}>1000 \pm \\
0.00\end{array}$ \\
\hline A. acidocaldarius $0299^{\mathrm{T}}$ & $\begin{array}{l}125 \pm \\
0.00\end{array}$ & $\begin{array}{l}250 \pm \\
0.00\end{array}$ & $\begin{array}{l}1000 \pm \\
0.00\end{array}$ & $\begin{array}{l}1000 \pm \\
0.00\end{array}$ \\
\hline $\begin{array}{l}\text { Salmonella Enteritidis ATCC } \\
\quad 13076\end{array}$ & $\begin{array}{l}1000 \pm \\
0.00\end{array}$ & $\begin{array}{l}>1000 \pm \\
0.00\end{array}$ & $\begin{array}{l}>1000 \pm \\
0.00\end{array}$ & $\begin{array}{l}>1000 \pm \\
0.00\end{array}$ \\
\hline $\begin{array}{l}\text { Staphylococcus aureus ATCC } \\
25923\end{array}$ & $\begin{array}{l}125 \pm \\
0.00\end{array}$ & $\begin{array}{l}1000 \pm \\
0.00\end{array}$ & $\begin{array}{l}1000 \pm \\
0.00\end{array}$ & $\begin{array}{l}>1000 \pm \\
0.00\end{array}$ \\
\hline
\end{tabular}

Results expressed as mean \pm standard deviation.
Gram-negative $P$. aeruginosa. The authors obtained a reduction of $1.2 \mathrm{log}$ $\mathrm{CFU} / \mathrm{mL}$ in the count of $S$. aureus cells, and $1 \log \mathrm{CFU} / \mathrm{mL}$ for $P$. aeruginosa, when using a concentration of $1 \mathrm{mg} / \mathrm{mL}$ of the curcuminsilica nanoparticles. The Gram-positive bacteria demonstrated a greater susceptibility to these nanoparticles in LED light, probably due to the difference in their cell wall structure. Gram-positive cells have a cytoplasmic membrane covered by a simple cell wall, which would facilitate the internalization of photosensitizers. However, in the present study a more significant reduction, equal to $4 \log \mathrm{CFU} / \mathrm{mL}$, was obtained with the curcumin-loaded nanoparticle (at a concentration of $125 \mu \mathrm{g} / \mathrm{mL}$ ) against $S$. aureus, with a smaller reduction against the Gram-positive Alicyclobacillus strains tested.

Rai et al. (2008) identified the mechanism of antimicrobial action of curcumin as targeting FtsZ, a prokaryotic homologue of the eukaryotic cytoskeleton protein, tubulin. FtsZ is responsible for forming the $\mathrm{Z}$ ring in the intermediate cell that leads to bacterial division and multiplication. Curcumin in contact with FtsZ leads to a disturbance in the formation of this ring that inhibits bacterial cytokinesis. Strong inhibition of cytokinetic $\mathrm{Z}$ ring formation by curcumin was observed in Bacillus subtilis 168. The curcumin bound to FtsZ in vitro with a dissociation constant of $7.3 \pm 1.8 \mu \mathrm{M}$, in addition to increasing GTPase. Therefore, the authors concluded that by disturbing the GTPase activity of FtsZ ring assembly, curcumin is lethal to bacteria, inhibiting cell proliferation (Figure Supplementary Fig. 1).

\subsection{Cytotoxicity in cell lines}

The results obtained from the cytotoxicity assay with cell lines are presented in Fig. 5.

Nanoencapsulated curcumin showed increased anti-tumoral potential against the four cell lines evaluated, when compared to free form curcumin. The most effective nanoparticle action was against the gastric adenocarcinoma (AGS), since the $\mathrm{GI}_{50}$ concentration determined was 4.1-fold higher than curcumin in its free form. Nanoparticles presented the following importance against the tumor cell lines: AGS > MCF7 > NCI-60 > Caco-2. It is worth noting that the encapsulating agent (PVP) presented low cytotoxicity against all the cell lines, including the nontumor PLP-2 and Vero cells. Furthermore, encapsulation modulated the cytotoxicity of curcumin against PLP-2 and Vero cells, reducing its cytotoxic effect. Santos et al. (2019) also found that with the curcuminoids (curcumin, demethoxy curcumin, and bisdemethoxycurcumin) encapsulation in PVP there was a decrease in the cytotoxicity against PLP-2 cells. Also, in relation to PLP-2 cells, Almeida et al. (2018a, 2018b) found the same pattern between unencapsulated curcumin and the curcumin encapsulated in PVP under the same conditions applied in the present work. According to Chankhampan et al. (2014), the use of biocompatible polymers in the encapsulation process allows a better toleration by the cells. Still, according to González et al. (2019), these compounds avoid normal tissues and accumulate only in tumors, due to the action of nanocarriers. In work presented by Niza et al. (2019), doxorubicin was encapsulated in devices based on tailored bare polycaprolactone with the intent of acting on glioblastoma. The authors evaluated the cytotoxicity against the tumor cell lines (C6, U87, A2780S, and A2780R), as well as against non-tumor cell lines (astrocytes and murine macrophages as these are immune cells present in the surrounding tissue of the tumor). Results showed that the treatment of nontumor cells with free doxorubicin induced a drastic reduction of mitochondrial function that was significantly lower when these cells were treated with nanoencapsulated doxorubicin. This suggested that there was sustained released of the drug from the nanocarrier, which allowed the cytotoxic effect on the tumor cells whilst reducing the cytotoxic effect in the surrounding healthy tissue.

\subsection{Antioxidant capacity}

The antioxidant capacity of the nanoencapsulated curcumin, in 
Gastric adenocarcinoma (AGS)

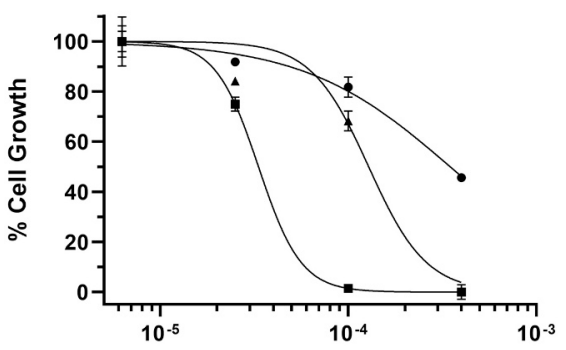

[Sample] g/mL

$$
*{ }^{*}|*| \begin{aligned}
* & \rightarrow \text { PVP; } \mathrm{GI}_{50}=348.6 \pm 54,8 \mu \mathrm{g} / \mathrm{mL} \\
& \rightarrow \text { Nanoparticles; } \mathrm{GI}_{50}=33.29 \pm 4,9 \mu \mathrm{g} / \mathrm{mL} \\
& \rightarrow \text { Curcumin; } \mathrm{Gl}_{50}=136.9 \pm 28,4 \mu \mathrm{g} / \mathrm{mL}
\end{aligned}
$$

Breast carcinoma (MCF7)

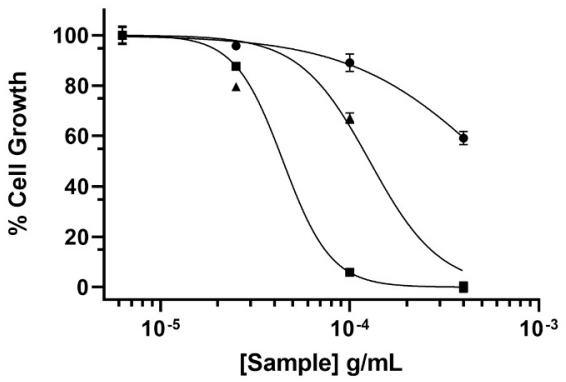

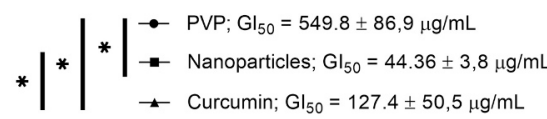

Non-tumour culture from African green monkey (Vero)

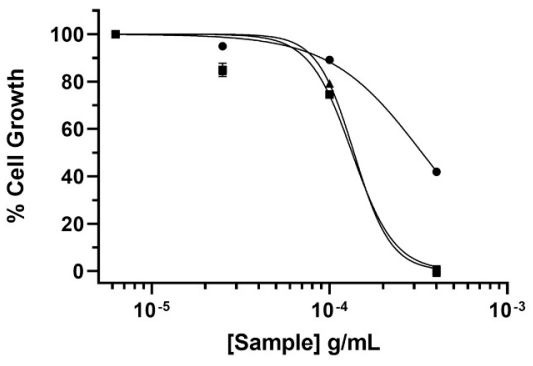

$$
* \mid \begin{aligned}
* \mid \begin{array}{l} 
\\
*
\end{array} & \text { PVP; } \mathrm{GI}_{50}=330.9 \pm 29,0 \mu \mathrm{g} / \mathrm{mL} \\
& \simeq \text { Nanoparticles; } \mathrm{GI}_{50}=133.8 \pm 44,8 \mu \mathrm{g} / \mathrm{mL}
\end{aligned}
$$

Colorectal adenocarcinoma (Caco-2)

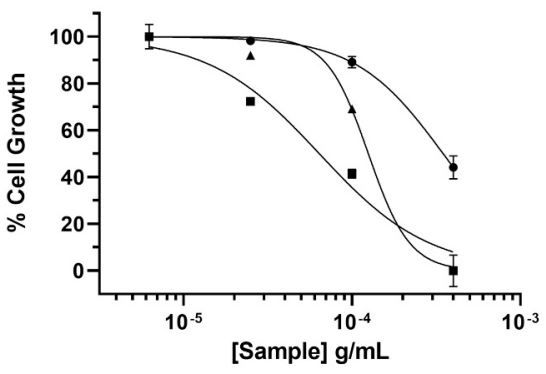

$* \mid * \begin{aligned} * & \rightarrow \text { PVP; } \mathrm{GI}_{50}=348.0 \pm 29,5 \mu \mathrm{g} / \mathrm{mL} \\ & \rightarrow \text { Nanoparticles; } \mathrm{GI}_{50}=64.04 \pm 18,1 \mu \mathrm{g} / \mathrm{mL} \\ & \rightarrow \text { Curcumin; } \mathrm{GI}_{50}=125.2 \pm 28,4 \mu \mathrm{g} / \mathrm{mL}\end{aligned}$

Non-small cell lung carcinoma ( $\mathrm{NCl}-60)$

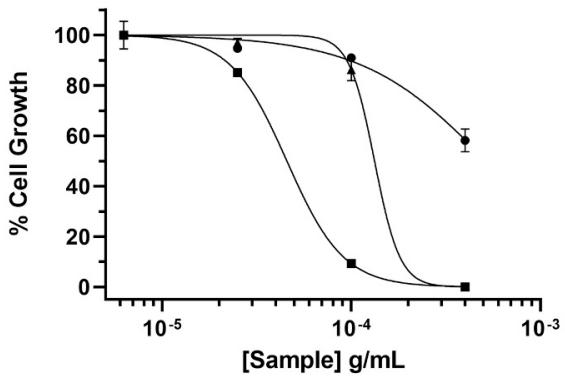

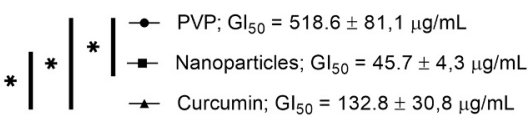
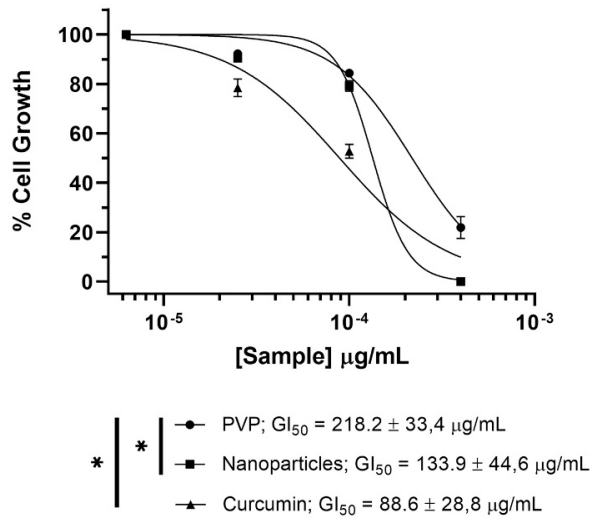

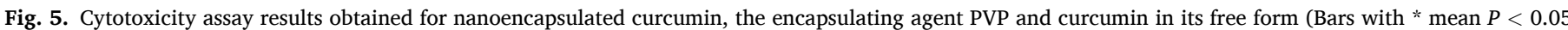
between the samples). 
terms of lipid peroxidation inhibition (TBARS) and antihemolytic activity, is presented in Table 2.

The TBARS assay provides information on the compound's capacity to inhibit the formation of thiobarbituric acid reactive substances, such as malondialdehyde generated from the ex vivo decomposition of lipid peroxidation products. It is possible to observe in Table 2 that free form curcumin had higher antioxidant capacity when compared to the nanoencapsulated curcumin $(P<0.05)$. The same behavior was identified by Santos et al. (2019), as the authors found an IG I0 $_{50}$ 11.4-fold higher for curcuminoids when compared to the encapsulated curcuminoids. In the present work there was a significant difference detected $(P$ $<0.05$ ), however this difference was only 1.2 -fold higher.

In relation to the oxidative hemolysis inhibition assay (OxHLIA), the $\mathrm{IC}_{50}$ values $(\mu \mathrm{g} / \mathrm{mL})$ at $\Delta \mathrm{t} 60 \mathrm{~min}$ were determined, that is, the concentration required to protect $50 \%$ of the erythrocyte population (P) from the hemolytic action caused by the used oxidizing agent for $60 \mathrm{~min}$. Peroxyl radicals generated from 2,2'-azobis(2-methylpropionamidine) dihydrochloride (AAPH) attack the biomembranes of erythrocytes and eventually cause hemolysis, that can be inhibited by antioxidant activities. This test presents many advantages over DPPH and ORAC $\mathrm{FL}_{\text {, }}$ especially as the results obtained reflect biologically relevant radicalscavenging activity (Takebayashi et al., 2012). Results presented in Table 2 show that the action of nanoencapsulated curcumin is statistical the same of free form curcumin at $\Delta \mathrm{t} 60 \mathrm{~min}(P>0.05)$. On the other hand, the encapsulating agent (PVP) did not show expressive antioxidant capacity when compared to the nanoparticles, curcumin, and Trolox. It is worth noting that to make the curcumin evaluation possible (for both TBARS and OxHLIA), it was first dissolved in DMSO due to its poor water solubility. In this sense nanoencapsulated curcumin reaches the goal of bioavailability with efficient water dispersion and action in simulated biological systems.

In their review, Kunnumakkara et al. (2019) described the extensive therapeutic potential of curcumin through several clinical trials, combating chronic diseases such as cardiovascular disease, inflammatory disease, metabolic disease, neurological disease, skin disease, liver disease, and various types of cancer. It was suggested that oral or topical curcumin was mostly well tolerated. Through the association of curcumin with other compounds or formulations, such as in the form of nanoparticles, micelles, liposomes, phospholipids, and exosomes, the bioavailability of this compound is greatly enhanced. In another review, Nair et al. (2019) analyzed the anti-cancer effects of the noncurcuminoid compounds present in the curcuma rhizome in various formulations and noted that their effect can be complementary to that of curcuminoids, thus enabling the joint use of these compounds in natural cancer treatments.

\subsection{Technological properties of nanoencapsulated curcumin in orange} juice

Bacteria of the genus Alicyclobacillus can affect the quality of industrially processed juices (Prado et al., 2019). Since curcumin nanoparticles presented promising results against these bacteria, the technological properties of juice were evaluated following the

Table 2

Antioxidant capacity evaluation of encapsulated curcumin (nanoparticles), the encapsulating agent (PVP) and in natura curcumin.

\begin{tabular}{lll}
\hline & TBARS $\left(\mathrm{IC}_{50} ; \mu \mathrm{g} / \mathrm{mL}\right)$ & OxHLIA $\left(\mathrm{IC}_{50} ; \mu \mathrm{g} / \mathrm{mL}\right) \Delta \mathrm{t}=60 \mathrm{~min}$ \\
\hline PVP & $\mathrm{Nd}^{*}$ & $1838.5^{\mathrm{c}} \pm 27.2$ \\
Nanoparticles & $78.0^{\mathrm{c}} \pm 2.9$ & $84.0^{\mathrm{b}} \pm 3.0$ \\
Curcumin & $63.0^{\mathrm{b}} \pm 2.7$ & $99.0^{\mathrm{b}} \pm 2.0$ \\
Trolox & $5.4^{\mathrm{a}} \pm 0.2$ & $21.8^{\mathrm{a}} \pm 0.2$ \\
\hline
\end{tabular}

$\mathrm{Nd}^{*}$ - not detected; Results expressed as mean \pm standard deviation; ${ }^{\mathrm{a}, \mathrm{b}, \mathrm{c}}$ different letters in the same column indicate significant difference between the treatments by Tukey's test $(P<0.05)$. incorporation of the nanoparticles in order to determine the feasibility of their use in the food industry.

Color parameters and $\mathrm{pH}$ of the orange juice prepared with nanoencapsulated curcumin are presented in Fig. 6. The MIC applied in the tests was equal to $125 \mu \mathrm{g} / \mathrm{mL}$, since $A$. herbarius $0246^{\mathrm{T}}$ was the most resistant microorganism, among the Alicyclobacillus strains tested (Table 1). The addition of nanoparticles, as well as the storage time, did not affect significantly affect the ${ }^{\circ}$ Brix results.

There was a significant difference $(P<0.05)$ in the $\mathrm{pH}$, mainly associated with the storage time, but not between the orange juice with and without the nanoparticles. This result is likely due to the acid hydrolysis of polysaccharides into monosaccharides and disaccharides (Singh and Sharma, 2017). Similar results were obtained by Porto et al. (2017) and Azadbakht et al. (2021).

The addition of nanoparticles significantly affected all the color parameters. A significant decrease in luminosity $\left(\mathrm{L}^{*}\right)$ occurred when nanoparticles were added at the 10 and 5-fold MIC concentrations, when compared to the control. After 3 days of storage, the control samples did not show $L^{*}$ variation when compared to the initial day of evaluation. All the other samples presented significantly lower $L^{*}$ values. On the other hand, a significant increase in the $\mathrm{a}^{*}$ parameter was detected (redness tendency for positive $\mathrm{a}^{*}$ values) when nanoparticles were added, which was expected since the nanoparticles have an orangeyellow color. Also, a significant increase in the b* parameter was found when the nanoparticle concentration was increased. Storage time affected the $a^{*}$ and $b^{*}$ parameters of all the samples, with the exception of the control and the 5-fold MIC samples that remained constant over the three days.

Hue angle $\left({ }^{\circ} \mathrm{h}\right)$ and chroma $\left(\mathrm{C}^{*}\right)$ that represent color classification (red, yellow, blue, etc.) and saturation or intensity respectively, are derived from $\mathrm{a}^{*}$ and $\mathrm{b}^{*}$. These parameters may accurately describe color measurements and are more effective for the judgement of color analysis (McGuire, 1992). The ${ }^{\circ} \mathrm{h}$ scale indicates a yellowish color for values in the range of $90^{\circ}$, and reddish color in the range of $0^{\circ}$ (Nanda et al., 2020). In Fig. 6 it is possible to observe that control samples tended to be yellow while nanoparticles added to the orange juice had lower ${ }^{\circ} \mathrm{h}$ values, associated with an orange color (yellow and red mixtures). Higher $C^{*}$ values were obtained for orange juice samples with the nanoencapsulated curcumin, thus showing a more saturated color when compared to the control. Color saturation was statistically the same during the storage time for the 5-fold MIC sample. According to Lee et al. (2013), the food color with a higher chroma value is preferred by consumers, moreover, in the case of yellowish foods, a higher hue angle is also preferred. The orange juice samples with nanoparticles added at the 5 -fold MIC concentration should be submitted to a sensory analysis test to confirm this hypothesis, since it showed high values of both hue angle and chroma, as well as good color stability during the storage time.

The results obtained for the antimicrobial test of the nanoparticles in reconstituted orange juice are shown in Fig. 7; these showed a reduction in the microbial concentration with the different nanoparticle concentrations applied, confirming the results obtained in vitro. The positive control showed a growth of $6.31 \log \mathrm{CFU} / \mathrm{mL}$ of $A$. acidoterrestris $0244^{\mathrm{T}}$, after $24 \mathrm{~h}$, while the growth following application of $1 \times$ MIC of the nanoparticles $(62.5 \mu \mathrm{g} / \mathrm{mL})$ was $4.52 \log \mathrm{CFU} / \mathrm{mL}$, for $4 \times \mathrm{MIC}(250 \mu \mathrm{g} /$ $\mathrm{mL}$ ) the growth was $2.46 \log \mathrm{CFU} / \mathrm{mL}$, and for $8 \times \mathrm{MIC}(500 \mu \mathrm{g} / \mathrm{mL})$ the growth was $1.04 \log \mathrm{CFU} / \mathrm{mL}$. Thus, the application of nanoparticles at a concentration of $8 \times$ MIC reduced $A$. acidoterrestris contamination in orange juice by more than $5 \operatorname{logs} \mathrm{CFU} / \mathrm{mL}$, indicating its possible use as an antimicrobial agent in citrus beverage industries.

\section{Conclusion}

Curcumin encapsulated in polyvinylpyrrolidone (PVP) nanoparticles showed antimicrobial and antibacterial activities against strains of Alicyclobacillus spp., as well as against the pathogenic bacteria, S. aureus and Salmonella Enteritidis, and the spores of A. acidoterrestris. The 

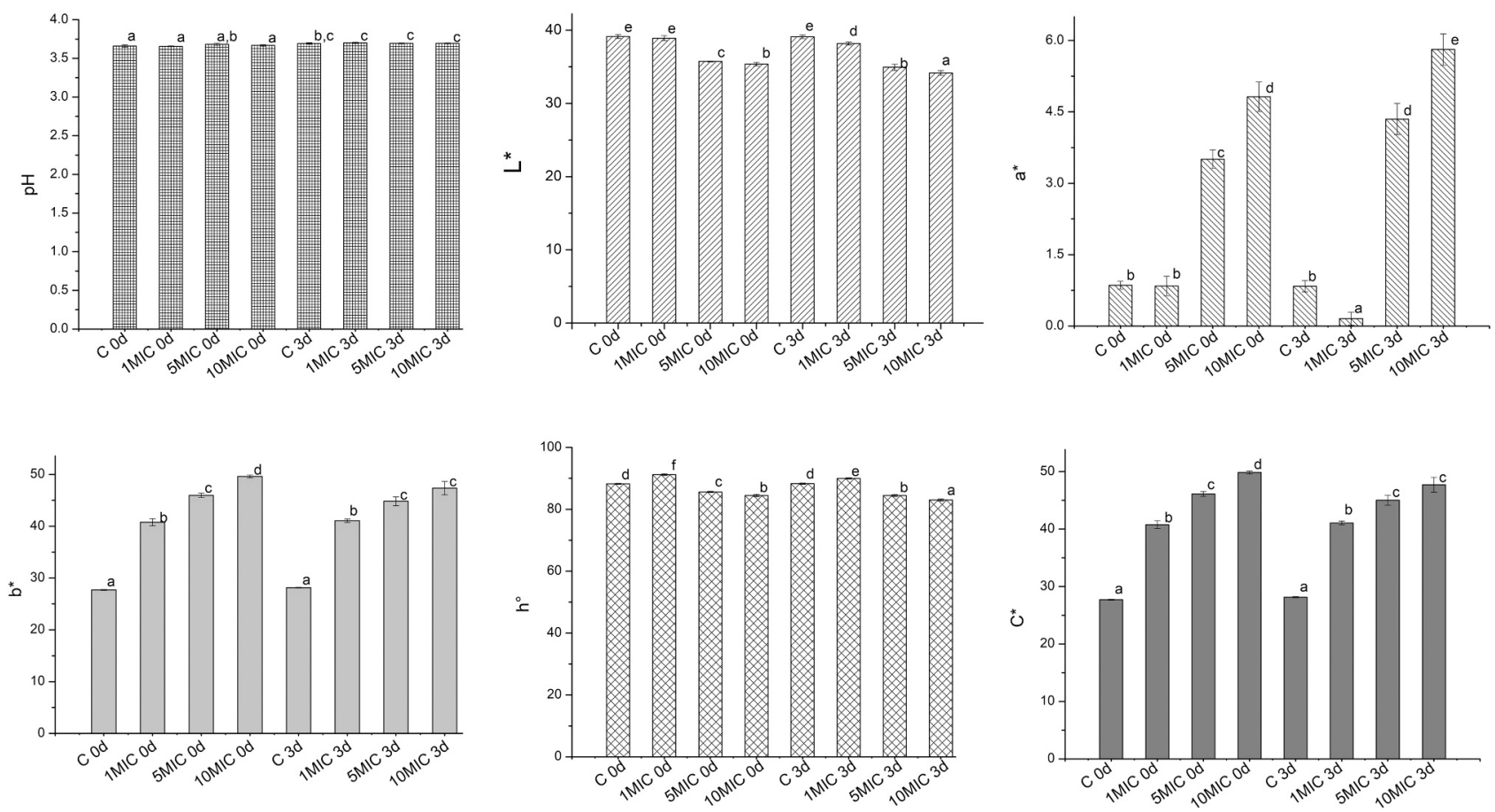

Fig. 6. Technological properties ( $\mathrm{pH}$, color parameters: $\mathrm{L}^{*}$ (luminosity), $\mathrm{a}^{*}$ (from green $(-)$ to red $(+)$ ), and $\mathrm{b}^{*}$ (from blue $(-)$ to yellow $(+)$, $\mathrm{h}^{\circ}$ (hue angle) and $\mathrm{C}^{*}$ (chroma)) of the orange juice added with nanoencapsulated curcumin: control, 1MIC $0 \mathrm{~d}$ (1-fold MIC, 0 day of storage); 5 MIC $0 \mathrm{~d}$ (5-fold MIC, 0 day of storage), $10 \mathrm{MIC} 0 \mathrm{~d}$ (10-fold MIC, 0 day of storage), 1MIC $3 \mathrm{~d}$ (1-fold MIC, 3 days of storage), 5MIC $3 \mathrm{~d}$ (5-fold MIC, 3 days of storage), 10MIC $3 \mathrm{~d}$ (10-fold MIC, 3 days of storage). MIC $=125 \mu \mathrm{g} / \mathrm{mL}$. a,b Averages followed by different letters presents significant difference by Tukey's test $(P<0.05)$. (For interpretation of the references to color in this figure legend, the reader is referred to the web version of this article.)

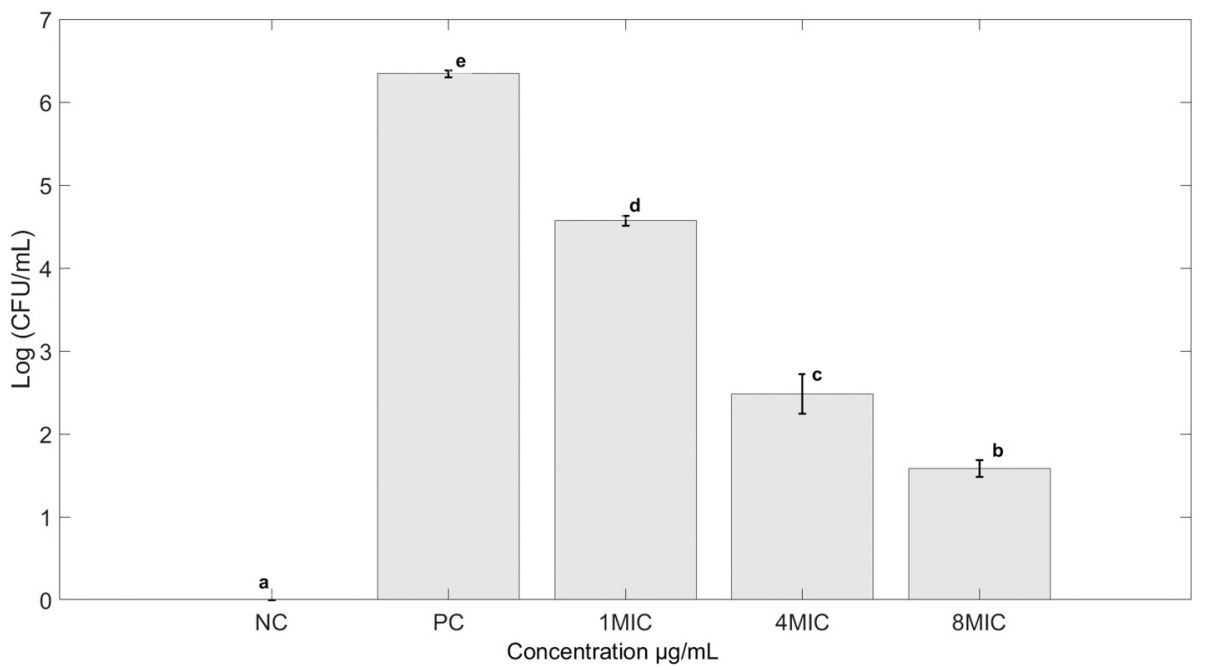

Fig. 7. Antimicrobial activity of nanoparticles against A. acidoterrestris $0244^{\mathrm{T}}$ in reconstituted orange juice for $24 \mathrm{~h}$ at $45{ }^{\circ} \mathrm{C}$. Concentrations of the curcumin nanoparticles in MIC values, wherein 1MIC is equal to $62.5 \mu \mathrm{g} / \mathrm{mL}$, 4MIC is equal to $250 \mu \mathrm{g} / \mathrm{mL}$ and $8 \mathrm{MIC}$ is equal to $1000 \mu \mathrm{g} / \mathrm{mL}$.

*NC: negative control; PC: positive control. Averages followed by different letters presents significant difference by Anova and Tukey's test $(P<0.05)$.

thermal characterization of the nanoparticles by DSC demonstrated that curcumin is in its amorphous phase, due to its interaction with PVP, as corroborated by FTIR spectra. TEM images demonstrated a large size distribution of the nanoparticles. The cytotoxicity of encapsulated curcumin against non-tumor cell lines was reduced, when compared to in natura (free form) curcumin. These findings demonstrate the stability of the nanoparticles. This study highlights the importance of choosing an encapsulating agent that potentiates the effects of the compound to be studied, in this case curcumin with PVP. This nanoparticle combination resulted in an improvement in the antimicrobial capacity, as well as a reduction in toxicity, providing an alternative natural product to be used by the food industry to combat microbial contamination. The produced nanoparticles were incorporated into orange juice samples, under two concentrations, as defined by the MIC of the most resistant Alicyclobacillus strain. When applied at the 5-fold MIC concentration, good $\mathrm{pH}$, ${ }^{\circ} \mathrm{Brix}$, and color stability were determined during three days of storage $\left(8{ }^{\circ} \mathrm{C}\right)$, which should be studied further in terms of sensory preference. 


\section{Declaration of competing interest}

The authors declare that they have no known competing financial interests or personal relationships that could have appeared to influence the work reported in this paper.

\section{Acknowledgements}

This study was financed in part by the Coordenação de Aperfeiçoamento de Pessoal de Nível Superior - Brasil (CAPES) - Finance Code 001. The authors thank the "Central Analítica Multiusuário da UTFPR Campo Mourão" (CAMulti-CM) for the analyses. Fernanda V. Leimann (process 039/2019) would like to thank Fundação Araucária (CP 15/2017- Programa de Bolsas de Produtividade em Pesquisa e Desenvolvimento Tecnológico) and CNPq (process number 421541/2018-0, Chamada Universal MCTIC/CNPq ${ }^{\circ}$ 28/2018). The authors are also grateful to the Foundation for Science and Technology (FCT, Portugal) for financial support through national funds FCT/MCTES to CIMO (UIDB/00690/ 2020); L. Barros and C. Pereira also thank FCT, P.I., through the institutional scientific employment program-contract.

\section{Appendix A. Supplementary data}

Supplementary data to this article can be found online at https://doi. org/10.1016/j.ijfoodmicro.2021.109442.

\section{References}

Abreu, R.M.V., Ferreira, I.C.F.R., Calhelha, R.C., Lima, R.T., Vasconcelos, M.H., Adega, F., Chaves, R., Queiroz, M.J.R.P., 2011. Anti-hepatocellular carcinoma activity using human HepG2 cells and hepatotoxicity of 6-substituted methyl 3aminothieno[3,2-b]pyridine-2-carboxylate derivatives: in vitro evaluation, cell cycle analysis and QSAR studies. Eur. J. Med. Chem. 46, 5800-5806. https://doi.org/ 10.1016/j.ejmech.2011.09.02.

Almeida, H.H.S., Barros, L., Barreira, J.C.M., Calhelha, R.C., Heleno, S.A., Sayer, C., Miranda, C.G., Leimann, F.V., Barreira, M.F., Ferreira, I.C.F.R., 2018. Bioactive evaluation and application of different formulations of the natural colorant curcumin (E100) in a hydrophilic matrix (yogurt). Food Chem. 261, 224-232. https://doi.org/ 10.1016/j.foodchem.2018.04.056.

Almeida, M., Rocha, B.A., Francisco, C.R.L., Miranda, C.G., Santos, P.D.F., Araújo, P.H. H., Sayer, C., Leimann, F.V., Gonçalves, O.H., Bersani-Amado, C.A., 2018. Evaluation of the in vivo acute antiinflammatory response of curcumin-loaded nanoparticles. Food Funct. 9, 440-449. https://doi.org/10.1039/c7fo01616f.

Anjos, M.M., Silva, A.A., Pascoli, I.C., Mikcha, J.M.G., Machinski Jr., M., Peralta, R.M., Abreu Filho, B.A., 2016. Antibacterial activity of papain and bromelain on alicyclobacillus spp. Int. J. Food Microbiol. 216, 121-126. https://doi.org/10.1016/ j.ijfoodmicro.2015.10.007.

Azadbakht, M., Rezaeiasl, A., Mahmoodi, M.J., Torshizi, M.V., Shabankareh, S.H., 2021 Evaluation of ambient light and moisture, and edible coatings in diferent storage period, on pressurized kiwifruit antioxidant properties. J. Food Meas. Characterization 15, 697-706. https://doi.org/10.1007/s11694-020-00674-z.

Bevilacqua, A., Sinigaglia, M., Corbo, M.R., 2008. Alicyclobacillusacidoterrestris: new methods for inhibiting spore germination. Int. J. Food Microbiol. 125, 103-110. https://doi.org/10.1016/j.ijfoodmicro.2008.02.030.

Cai, R., Zhang, M., Cui, L., Yuan, Y., Yang, Y., Wang, Y., Yue, T., 2019. Antibacterial activity and mechanism of thymol against alicyclobacillusacidoterrestris vegetative cells and spores. LWT Food Sci. Technol. 105, 377-384. https://doi.org/10.1016/j lwt.2019.01.066.

Chang, S.S., Kang, D.H., 2004. Alicyclobacillus spp. In the fruit juice industry: history, characteristics, and current isolation/detection procedures. Crit. Rev. Microbiol. 30, 55-74. https://doi.org/10.1080/10408410490435089.

Chankhampan, C., Manosroi, J., Yamamoto, H., Tahara, K., Manosroi, W., Kawashima, Y., Manosroi, A., 2014. Chemical stability enhancement and cytotoxicity reduction of papain loaded in PLGA nanospheres. J. Exp. Nanosci. 9 (2), 138-151. https://doi.org/10.1080/17458080.2011.636385.

Ciuffreda, E., Bevilacqua, A., Sinigaglia, M., Corbo, M.R., 2015. Alicyclobacillus spp.: new insights on ecology and preserving food quality through newapproaches. Microorganisms 3 (4), 625-640. https://doi.org/10.3390/microorganisms3040625.

CLSI - Clinical and Laboratory Standards Institute, 2012. Methods for Diluition Antimicrobial Susceptibility Tests for Bacteria That Grow Aerobically, Approved Standard. No. 2 In: CLSI document M07 - A9, 9th ed., Vol. 32 file:///C:/Users/User/ Downloads/03-CLSI-M07-A9-2012.pdf.

Deinhard, G., Blanz, P., Poralla, K., Altan, E., 1987. Bacillus acidoterrestris sp. nov., a new thermotolerant acidophile isolated from different soils. Syst. Appl. Microbiol. 10, 47-53. https://doi.org/10.1016/S0723-2020(87)80009-7.

Dong, W., Su, X., Xu, M., Hu, M., Sun, Y., Zhang, P., 2018. Preparation, characterization, and in vitro/ in vivo evaluation of polymer-assisting formulation of atorvastatin calcium based on solid dispersion technique.Asian. J. Pharm. Sci. 13, 546-554. https://doi.org/10.1016/j.ajps.2018.08.010.

Dutra, T.V., Castro, J.C., Menezes, J.L., Ramos, T.R., Prado, I.N., Machinski Junior, M., Mikcha, J.M.G., Abreu Filho, B.A., 2019. Bioactivity of oregano (Origanum vulgare) essential oil against alicyclobacillus spp. Ind. Crop. Prod. 129, 345-349. https://doi. org/10.1016/j.indcrop.2018.12.025.

Evans, B.C., Nelson, C.E., Yu, S.S., Beavers, K.R., Kim, A.J., Li, H., Nelson, H.M., Giorgio, T.D., Duvall, C.L., 2013. Ex vivo red blood cell hemolysis assay for the evaluation of $\mathrm{pH}$-responsive endosomolytic agents for cytosolic delivery of biomacromolecular drugs. J. Vis. Exp. 73, e50166 https://doi.org/10.3791/50166.

Gonçalves, O.H., Moreira, T.F.M., Oliveira, A., Bracht, L., Ineu, R.P., Leimann, F.V., 2020. Antioxidant activity of encapsulated extracts and bioactives from natural sources. Curr. Pharm. Des. 26, 1-15. https://doi.org/10.2174/ 1381612826666200707131500.

González, M.I.A., Quirós, L.A.C., Elizondo, M.J.G., Alfaro, J.J.R., Baudrit, J.V., 2019. Nanocarrier applied in the distribution of drugs in the assistance for the cancer treatment. Am. J. Biomed. Sci. Res. 5 (6), 469-480. https://doi.org/10.34297/ AJBSR.2019.05.000970. AJBSR.MS.ID.000970.

Goto, K., Matsubara, H., Mochida, K., Matsumura, T., Hara, Y., Niwa, M., Yamasato, K., 2002. Alicyclobacillusherbarius sp. Nov., a novel bacterium containing $\omega$-cycloheptane fatty acids, isolated from herbal tea. Int. J. Syst. Evol. Microbiol. 52, 109-113. https://doi.org/10.1099/00207713-52-1-109.

Karavas, E., Ktistis, G., Xenakis, A., Georgarakis, E., 2006. Effect of hydrogen bonding interactions on the release mechanism of felodipine from nanodispersions with polyvinylpyrrolidone. Eur. J. Pharm. Biopharm. 63, 103-114. https://doi.org/ 10.1016/j.ejpb.2006.01.016.

Kunnumakkara, A.B., Harsha, C., Banik, K., Sailo, B.L., Bordoloi, D., Rajesh, V., Gupta, S. C., Aggarwal, B.B., 2019. Is curcumin bioavailability a problem in humans: lessons from clinical trials. Expert Opin. Drug Metab. Toxicol. 1744-7607 https://doi.org/ 10.1080/17425255.2019.165091.

Lee, S.M., Lee, K.T., Lee, S.H., Song, J.K., 2013. Origin of human colour preference for food. J. Food Eng. 119-3, 508-515. https://doi.org/10.1016/j. jfoodeng. 2013.06.021.

Leimann, F.V., Gonçalves, O.H., Sorita, G.D., Rezende, S., Bona, E., Fernandes, I.P.M., Ferreira, I.C.F.R., Barreiro, M.F., 2019. Heat and pH stable curcumin-based hydrophilic colorants obtained by the solid dispersion technology assisted by spraydrying. Chem. Eng. Sci. 205, 248-258. https://doi.org/10.1016/j.ces.2019.04.044.

Lemes, G.F., Marchiore, N.G., Moreira, T.F.M., Da Silva, T.B.V., Sayer, C., Shirai, M.A., Gonçalves, O.H., Gozzo, A.M., Leimann, F.V., 2017. Enzymatically crosslinked gelatin coating added of bioactive nanoparticles and antifungal agent: effect on the quality of benitaka grapes. LWT Food Sci. Technol. 84, 175-182. https://doi.org/ 10.1016/j.lwt.2017.05.050.

Lyu, Y., Yu, M., Liu, Q., Zhang, Q., Liu, Z., Tian, Y., Li, D., Mu, C., 2020. Synthesis of silver nanoparticles using oxidized amylose and combination with curcumin for enhanced antibacterial activity. Carbohydr. Polym. 230, 115573 https://doi.org/ 10.1016/j.carbpol.2019.115573.

Mahmood, K., Zuber, M., Salman, M., Anjum, M., 2015. Recent developments in curcumin and curcumin based polymeric materials for biomedical applications: a review. Int. J. Biol. Macromol. 81, 877-890. https://doi.org/10.1016/j. ijbiomac.2015.09.026.

Mangolim, C.S., Moriwaki, C., Nogueira, A.C., Sato, F., Baesso, M.L., Neto, A.M., Matioli, G., 2014. Curcumin-b-cyclodextrin inclusion complex: stability, solubility, characterisation by FT-IR, FT-raman, X-ray diffraction and photoacoustic spectroscopy, and food application. Food Chem. 153, 361-1310. https://doi.org/ 10.1016/j.foodchem.2013.12.067.

McGuire, R.G., 1992. Reporting of objective color measurements. Hortscience 27 (12), 1254-1255.

Miranda, C., Silva, J., Becker, D., Guerra, G., Leimann, F., Gonçalves, O., 2016. Characterization of lutein nanoparticles in PVP and effects on AChE enzyme activity in vitro. In: X Cisdem - International Forum Of La CátedraIberoamericanaSuizaDearrolo De Medicamentos 6th Symposium Of Mercosur Pharmaceutical Sciences 6th 6th Mercosur Food Sciences And Technology, 2016, Cascavel. Anais X Cisdem - International Forum Of La CátedraIberoamericana-Suiza De Derorolo De Medicentos 6th Symposium Of Mercosur Pharmaceutical Sciences 6th Science And Technology Of Mercosur Foods.

Mirzahosseinipour, M., Khorsandi, K., Hosseinzadeh, R., Ghazaeian, M., Shahidi, F.K., 2020. Antimicrobial photodynamic and wound healing activity of curcumin encapsulated in silica nanoparticles. Photodiagn. Photodyn. Ther. 29, 101639 https://doi.org/10.1016/j.pdpdt.2019.101639.

Mizuta, A.G., Menezes, J.L., Dutra, T.V., Ferreira, T.V., Castro, J.C., Silva, C.A.J., Pilau, E. J., Machinski Junior, M., Abreu Filho, B.A., 2020. Evaluation of antimicrobial activity of green tea kombucha at two fermentation time points against Alicyclobacillus spp. LWT Food Sci. Technol. 130, 109641 https://doi.org/10.1016/ j.lwt.2020.109641.

Nair, A., Amalraj, A., Jacob, J., Kunnumakkara, A.B., Gopi, S., 2019. Non-curcuminoids from turmeric and their potential in cancer therapy and anticancer drug delivery formulations. Biomolecules 9 (1), 13. https://doi.org/10.3390/biom9010013.

Nanda, C., Chattopadhyay, K., Reddy, R., Javith, M.A., Das, S.K., Balange, A.K., Nayak, B. B., Xavier, K.A.M., 2020. Evaluation of different conventional breading materials on functional quality attributes of battered and breaded fish cutlets. J. Aquat. Food Prod. Technol. 29 (7), 641-649. https://doi.org/10.1080/10498850.2020.1786205.

Niza, E., Castro-Osma, J.A., Posadas, I., Alonso-Moreno, C., Bravo, I., Garzón, A., Canales-Vázquez, J., Ceña, V., Lara-Sánchez, A., Albaladejo, J., Otero, A., 2019. Assessment of doxorubicin delivery devices based on tailored bare polycaprolactone against glioblastoma. Int. J. Pharm. 558, 110-119. https://doi.org/10.1016/j. ijpharm.2018.12.079. ISSN 0378-5173. 
Pascoli, I.C., Anjos, M.M., Silva, A.A., Lorenzetti, F.B., Cortez, D.A.G., Mikcha, J.M.G., Nakamura, T.U., Nakamura, C.V., Abreu Filho, B.A., 2018. Piperaceae extracts for controlling alicyclobacillusacidoterrestris growth in commercial orange juice. Ind. Crop. Prod. 116, 224-230. https://doi.org/10.1016/j.indcrop.2018.02.073.

Phunpee, S., Suktham, K., Surassmo, S., Jarussophon, S., Rungnim, C., Soottitantawat, A., Puttipipatkhachorn, S., Ruktanonchai, U.R., 2018. Controllable encapsulation of $\alpha$-mangostin with quaternized $\beta$-cyclodextrin grafted chitosan using high shear mixing. Int. J. Pharm. 538, 21-29. https://doi.org/10.1016/j. ijpharm.2017.12.016.

Piskernik, S., Klancnik, A., Demsar, L., Mozina, S.S., Jersek, B., 2016. Control of alicyclobacillus spp. Vegetative cells and spores in apple juice with rosemary extracts. Food Control 60, 205-214. https://doi.org/10.1016/j. foodcont.2015.07.018.

Rai, D., Singh, J.K., Roy, N., Panda, D., 2008. Curcumin inhibits FtsZ assembly: an attractive mechanism for its antibacterial activity, 410 (1), 147-155. https://doi. org/10.1042/bj20070891.

Santos, P.D.F., Francisco, C.R.L., Coqueiro, A., Leimann, F.V., Pinela, J., Calhelha, R.C., Ineu, R.P., Ferreira, I.C.F.R., Bona, E., Gonçalves, O.H., 2019. The nanoencapsulation of curcuminoids extracted from Curcuma longa L. and an evaluation of their cytotoxic, enzymatic, antioxidant and anti-inflammatory activities. Food Funct. 10, 573-582. https://doi.org/10.1039/c8fo02431f.

Shah, D., Savaliya, R., Patel, P., Kansara, K., Pandya, A., Dhawan, A., Singh, S., 2018. Curcumin ag nanoconjugates for improved therapeutic effects in cancer. Int. J. Nanomedicine 13, 75-77. https://doi.org/10.2147/ijn.s124696.

Silva, A.C., Santos, P.D.F., Silva, J.T.P., Leimann, F.V., Bracht, L., Gonçalves, O.H., 2018 Impact of curcumin nanoformulation on its antimicrobial activity. Trends Food Sci. Technol. 72, 74-82. https://doi.org/10.1016/j.tifs.2017.12.004.
Silva de Sá, I., Peron, A.P., Leimann, F.V., Bressan, G.N., Krum, B.N., Fachinetto, R., Pinela, J., Calhelha, R.C., Barreiro, M.F., Ferreira, I.C.F.R., Gonçalves, O.H., Ineu, R. P., 2019. In vitro and in vivo evaluation of enzymatic and antioxidant activity, cytotoxicity and genotoxicity of curcumin-loaded solid dispersions. Food Chem. Toxicol. 125, 29-37. https://doi.org/10.1016/j.fct.2018.12.037.

Singh, S.K., Sharma, M., 2017. Review on biochemical changes associated with storage of fruit juice. Int. J. Curr. Microbiol. App. Sci. 6 (8), 236-245. https://doi.org/ 10.20546/ijcmas.2017.608.032.

Spricigo, D.A., Bardina, C., Cortes, P., Liagostera, M., 2013. Use of a bacteriophage cocktail to controlSalmonella in the food and food industry. Int. J. Food Microbiol. 165, 169-174. https://doi.org/10.1016/j.ijfoodmicro.2013.05.009.

Takebayashi, J., Iwahashi, N., Ishimi, Y., Tai, A., 2012. Development of a simple 96-well plate method for evaluation of antioxidant activity based on the oxidative haemolysis inhibition assay (OxHLIA). Food Chem. 134, 606-610. https://doi.org/ 10.1016/j.foodchem.2012.02.086.

Tremarin, A., Canbaz, E.A., Brandão, T.R.S., Silva, C.L.M., 2019. Modelling Alicyclobacillusacidoterrestris inactivation in apple juice using thermo sonication treatments. LWT Food Sci. Technol. 102, 159-163. https://doi.org/10.1016/j. lwt.2018.12.027.

Wang, Z., Li, X., Zhao, Y., Yuan, Y., Cai, R., Yue, T., 2018. Synthesis of multifunctional fluorescent magnetic nanoparticles for the detection of Alicyclobacillus spp. in apple juice. Food Res. Int. 114, 104-113. https://doi.org/10.1016/j.foodres.2018.07.065.

WHO-World Health Organization, 2018. Key facts. Salmonella. https://www.who. int/news-room/fact-sheets/detail/salmonella-(nontyphoidal). 